\title{
Investigation of Teacher Job-Performance Model: Organizational Culture, Work Motivation and Job-Satisfaction
}

\author{
Wesly Hutabarat ${ }^{1}$ \\ ${ }^{1}$ Department of Chemistry, State University of Medan, Indonesia \\ Correspondence: Wesly Hutabarat, Department of Chemstry, Universitas Negeri Medan, Jl. Willem Ikandar Psr. \\ V. Medan Estate, Medan, Indonesia. Tel: 62-61-662-5970. E-mail: barathuta@gmail.com
}

Received: March 12, 2015 Accepted: April 17, 2015 Online Published: June 5, 2015

doi:10.5539/ass.v11n18p295 URL: http://dx.doi.org/10.5539/ass.v11n18p295

\begin{abstract}
The research is intended to develop a Teacher Job-performance Model by considering causal relationship between teacher job-performance determinants i.e. Organizational Culture, Organizational Structure, and Work Motivation.

It was found that path coefficient of organizational culture to work motivation is 0.333 at a significant level of $<$ 0.05 and $F=17.553$, where $F_{\text {calc. }}>F_{1 / 141}=3.908$, at $\alpha<0.05$. In addition, path coefficients of organizational culture and work motivation to job-satisfaction are 0.225 , and 0.263 respectively at a significant level of $<0.05$ and $\mathrm{F}=13.224$, where $\mathrm{F}_{\text {calc }}>\mathrm{F}_{2 / 140}=3.061$, at $\alpha<0.05$. Furthermore, path coefficients of organizational culture, work motivation and job-satisfaction to job-performanc are $0.269,0.236$, and 0.193 respectively at a significant level of $<0.05$, and $\mathrm{F}=17.261$, where $\mathrm{F}_{\text {calc. }}>\mathrm{F}_{3 / 139}=2.669$, at $\alpha<0.05$. Finally, indirect effect of organizational culture on job-satisfaction and job-peformance through work motivation is 0.087 , and 0.078 respectively. It is concluded that the Model suggested fits with data collected, as a result, it can be used for perdicting teacher job-performance, including teacher promotions and feedback for improving teacher performance.
\end{abstract}

Keywords: job-performance, job-satisfaction, organizational culture, work motivation

\section{Introduction}

It is known that Indonesian educational achievement is very low compared with other countries around the world. It can be seen from International Achievement Test Performance, Indonesia was ranked $50^{\text {th }}$ of 87 countries (Tienken, 2008, p. 10), then program for international student assessment reported that Indonesia was ranked $64^{\text {th }}$ of 65 countries (Pisa, 2012, p. 16). This result is generally related to teacher job-performance, because teachers are responsible for the success of students and student outcomes (Gultom, 2012, p. 8). In order to overcome the lowering Indonesian educational outcomes, since 2008 Idonesian governements have tried hard to promote teacher job-performance assessment through implementation of teacher professional certification and followed by granting certification allowance.This program was designed to train primary, secondary and high school teachers in order to improve teacher quality and competency. It is believed that teacher professional certification program would be able to enhance teacher work motivation and job-satusfaction which in turn would improve teacher job-performance.

In response to the low level educational achievement of the students, Indonesia tried to improve educational quality through introducing the Minister of State for Administrative and Bureaucratic Reforms Act No. 16, 2009, which intends to assess teacher performance (Gultom, 2012, p. 5). Assessement of teacher performance is generally carried out in real teaching and learning activities by school principals, teacher professional development boards or school superintendents (Gultom, 2012, p. 26).

Teachers who are professionally certified and granting certification alllowance would feel secure at their jobs, so they would be motivated and in turn satisfied, because job security is considered as an important parts of motivation. Therefore, motivation is considered to have important roles in school organizations since it results in high productivity of teachers, and organizational goals could be achieved efficiently. Usually, teacher behaviors change when they are motivated, and it would directly affect student achievements (Mustafa \& Othman, 2010, p. 259), but motivation differs within individual (Robbins, Judge, \& Sanghi, 2005, p. 139). It was reported that job-satisfaction is positively correlated with job-performance (Judge, Bono, Thorensen, \& Patton, 2001, p. 376). 
It is believed, teacher job-performance is one of the main factors that determines and affecting school outcomes which could be measured through observing teacher activities in real classroom teaching performance, including lesson preparation, teacher commitment, extra-curricula, supervision, effective leadership, motivation and morale (Adejumobi \& Ojikutu, 2013, p. 26).

\subsection{Statement of the Problems}

Job-performance has been known as the last target in organizations. It is very inportant to managers to consider in order to achieve productiviy targetted. For school context, teacher job-satisfaction is highly related to student outcomes as the end product of education. When teacher job-performance decreasing, student outcomes would also be decreasing. The two parties are related one to the other, consequently when attempting to enchance graduate quality, it is therefore, the teacher quality and performance need to improve appropriately. In relation to teacher job-performance improvement, it is necessary to consider job-performance determinant factors i.e. organizational culture, work motivation, and job-satisfaction. Therefore, the problems can be stated in the following:

1. Is there a direct effect of organizational culture on work motivation

2. Is there a direct effect of organizational culture on job-satisfaction

3. Is there a direct effect of work motivation on job-satisfaction

4. Is there a direct effect of organizational culture on job-performance

5. Is there a direct effect of work motivation on job-performance

6. Is there a direct effect of of job-satisfaction on job-performance

7. Is there an indirect effect of organizational culture on job-satisfaction through work motivation

8. Is there an indirect effect of organizational culture on job-performance through work motivation

9. Is there an indirect effect of organizational culture on job-performance through job-satisdaction

10. Is there an indirect effect of organizational culture on job-performance through work motivation and job-satisfaction.

11. Is there an indirect effect of work motivation on job-performance through job-satisfaction.

\subsection{Objective of the Study}

Based on the literature discussed above, the objective of the study is to develop a teacher job-performance model by taking into account determinant factors: organizational culture, work motivation, job-satisfaction and job-perfromance.

\section{Literature Review}

\subsection{Job-Performance}

Teacher Job-performance is considered as teacher observable behaviors related to outcomes which are relevant to educational goals (Cook, 2008, p. 3). One of the main factors affecting job-performance is work motivation, and it was found that there is a positive and significant relationship between teacher work motivation and job-performance (Inayatullah \& Jehangir, 2002, p. 78)

Motivation and performance are very important in determining organization success and outcomes. If external environment changed due to new technology developments, it is necessary to adopt the change, so it could motivate employees (Inayatullah \& Jehangir, 2002, p. 78). Therefore, in order to meet organizational changes, it is necessay to upgrade employee skills and competencies according to new technology developments, so they would be able to adopt into the new working environment (Latt, 2008). It was also found that motivated teachers are more satisfied than those less motivated, and it results in higher performance. (Iwu, Gwija, Benedict, \& Tengeh, 2013, p. 838). In relation to job-performance, it was also reported that organizational culture positively affects job-performance (Hanjun, Roberts, \& Chang-Hoan, 2006, p. 100). Therefore, it is presumed that job-performance is determined by organizatioal culture. job-satisfaction, and work motivation

\subsection{Job-Satisfaction}

Teacher Job satisfaction is defined as teacher feelings of happiness about his/her jobs (Cook, 2008, p. 2). Job satisfaction is referred to an emotional response to a job circumstance, so it is invisible, and can only be inferred. Job satisfaction is often determined by how well outcome meet or exceed objectives expected (Tella, Ayeni, \& Ppoola, 2007, p. 1). Teachers who worked in favorable good environment are more satisfied than those lack of 
working condition (Amstrong, 2012, p. 1). Higher motivated teachers were found to be more satisfied and perform better than less motivated (Iwu et al., 2013, p. 836). Therefore, it is presumed that there is a positive relationship between work motivation, job-satisfaction and job-performance.

\subsection{Work Motivation}

Work motivation is the process of stimulating people to do their jobs in order to achieve desired goals. One way of motivating people is to use effective motivation, which results in satisfied with and committed to their jobs (Tella, Ayeni, \& Ppoola, 2007, p. 2). Therefore, teacher work motivation is referred to inner and outer energies that initiate teacher activities, and to intensify direction, intensity, and duration in order to achieve teaching and learning objectives appropriately (Luthams \& Pinder, 2005, p. 486).

Teacher work motivation is classified into achievement motivation (n-ach), authority/power motivation (n-pow), and affiliation motivation (n-affil) (Bell, 2012, p. 11). The $\mathrm{n}$-ach teacher is achievement motivated and looks for achievement, and pursuing of realistic but challenging goals, He/she needs for achievement and progress feedbacks for a sense of accomplishment and satisfaction. Teacher with a high need for achievement would like to exceed and tend to avoid both low-risk and high-risk circumstances. High n-ach teacher prefers to work on a moderate probability of $50 \%$ chance of success. He/she prefers to work individually or with other high achievers (Bell, 2012, p. 12).

The n-pow teacher is authority motivated, which results in a need to be influential, effective and to lead and implement his/her ideas. The n-power teachers are usually motivated to increase personal status and prestige and direct others, and this need is often considered unsuitable. Meanwhile teachers who have institutional power want to manage the efforts of others to foster the goals of the organization. Therefore, teachers who have a high need for institutional power tend to be more effective than those with a high need for personal power (Bell, 2012, p. 12).

The $\mathrm{n}$-affil teacher is affiliation motivated, and tends to have friendly relationships and has a good interaction with other teachers. High n-affilteacher tends to obey the norms of school organiztions (Bell, 2012, p. 12).

The job-characteristic Model of Hackman and Oldham consists of skill variety, task identity, task significance, autonomy and job-feedback which are presumed affecting teacher's motivation (Siruri \& Muathe, 2014, p. 3).

\subsection{Organizatioal Culture}

Culture is defined as "the glue" that ties an organization together or "the compass" that stipulates directions. therefore, culture is important in shaping organizational performances (O'Donnel \& Boyle, 2008, p. 28; Peterson, 2002 , p. 1). In line with this, organizational culture can be defined as shared social which creates norms and basic assumptions within organizations (Wilkins \& Ouchi, 1983, p. 1; Schall, 1983, p. 5) The culture is generally created within organizations through shared experiences for certain periods. It admits organizational members to coordinate tasks comprehensively, comprehend and anticipate behaviors, truth and motivation of the organizational members (Weber, Camerer, \& Rock, 2006, p. 76). It was known that organizational culture determinants consist of (1) artifacts, (2) norms and values, (3) basic assumptions (Colquitt, LePine, \& Wesson. 2009, p. 456; Schein, 2004, p. 17).

\section{Methodology}

The research was carried out toward classroom teachers of 10 public high schools in Medan, Indonesia. The research is a causal espoused facts which is intended to uncover relationship between variables investigated. Organizational culture, work motivation and job-satisfaction data were colleted by distributing questionnaires to selected samples. Teacher job-performance data were collected by observing teacher samples in real teaching and learning process. Then, the data collected were analyzed using SPSS for Windows.

\subsection{Population and Samples}

The population of this investigation was 645 teachers of public high schools in Medan, Indonesia. 143 samples of 645 teachers were selected based on stratified random sampling techniques i.e. teaching experiences, teacher certificate of professionalism, and professional allowances except for guidance and counselor teachers.

\subsection{Instruments Tried Out}

Instruments for collecting organizational culture, work motivation, and job-satisfaction were questionnaires. The instruments were tried out to 30 teachers before conducting the investigation in order to find out instrument validity and reliability. The validated intruments were distributed to 143 teacher samples in the morning before classroom take places and during the breaks. 
In addition, job-performance obeservation sheets were tried out toward 30 teachers of public high schools in real teaching-learning classroom, in order to find out homogenity of teacher perceptions in using the instrument. 50 teacher observers were recruited to assist observeing real teaching-learning process in collecting job-performance data required.

\subsection{Procedures}

Organizatioal culture, work motivation and job-satisfaction questionnaires were distributed toward 143 samples selected in the morning before teahing and learning process take places and during the breaks. The objectives of the investigation was explained to the samples before distributing the questionnaires.

Furthermore, Job-performance asessment instrument for collecting job-performance data was observation sheets which were carried out during teaching and learning process. Sixty teachers were recruited as job-performance observers out side the sample selected. Each observer observed at least 3 teacher samples in real teaching-learning process. They were teachers who have 10 years of teaching experinces and certified, and granting for certification allowance regularly. The investigator teams have experienced in using the job-performance observation sheet which is called Alat penilaian kinerja guru (APKG) or teacher job-performance evaluation. This instrument has been used for years for assessing performance of teacher candidates in Indonesia, but it has never been related before towards organizational culture, work motivation and job-satisfaction as predictors of teacher job-performance. Therefore, the observers were able to use the instrument appropriately.

The organizational culture, work motivation and job-satisfaction questionnaires and job-performance observation sheet indicators are shown in the following Table 1.

Table 1. Questionnaires and observation sheets indicators

\begin{tabular}{llll}
\hline $\mathrm{X}_{1}$ indicators (34 items) & $\mathrm{X}_{2}$ indicators (30 items) & $\mathrm{X}_{3}$ indicators (34 items) & $\mathrm{X}_{4}$ indicators (31 items) \\
\hline Artifacts and Behaviors & Job-enlargement & Pay satisfaction & Apperception \\
Norms, Values and believes & Job-enrichment & Promotion satisfaction & Teacher attitudes \\
Basic Assumptions & Job-characteristic Model: & Social satisfaction & Teacher knowledge and ability \\
, & Task Significance & Supervision Satisfaction & Teaching-Learning Process \\
& Autonomy & Work-satisfaction & Teacher Ability in Using Media \\
& Feedback & Status Statisfaction & Evaluation \\
& & Environment Satisfaction & Closure \\
& & Co-Woker Satisfaction & Follow Up. \\
\hline
\end{tabular}

Data of organizational culture, work motivation, job-satisfaction and job-performance collected were organized into the following Table 2 and callculated wih SPSS for Windows.

Tabel 2. Data collected were organized in the following scheme ${ }^{b}$

\begin{tabular}{lllll}
\hline Respondents & Organizational Culture data & Work Motivation data & Job-satisfaction data & Job-performance data \\
\hline $\mathrm{N}=143$ & Scores: & Scores: & Scores: & Scores: \\
& Min $=34 ;$ & Min $=30 ;$ & Min $=34 ;$ & Min $=31 ;$ \\
& Max $=170$ & Max $=150$ & Max $=170$ & Max $=155$ \\
\hline
\end{tabular}

b. Using Likert's Scale with 5 options

\subsection{Data Analysis}

Based on the discussion above, instrument variables can be illustrated in the following diagram:

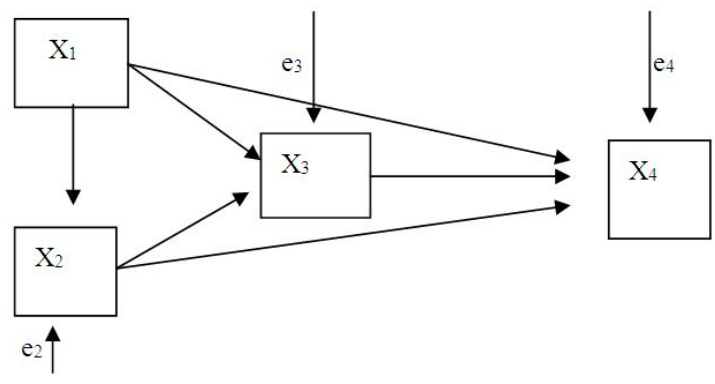

Figure 1. Causal relationship between $\mathrm{X}_{1}, \mathrm{X}_{2}, \mathrm{X}_{3}$ and $\mathrm{X}_{4}$ variables 
Oragnizational culture, $\mathrm{X}_{1}$, Work motivation, $\mathrm{X}_{2}$, Job-satisfaction, $\mathrm{X}_{3}$ and Job-performance, $\mathrm{X}_{4}$ data were collected and analyzed by SPSS for Windows vers. 21

\subsection{Null Hypotheses}

Based on the research paradigm above, the null hypotheses can be stated as follows:

$\mathrm{H}_{01}=$ There is no direct effect of organizational culture on work motivation.

$\mathrm{H}_{02}=$ There is no direct effect of organizational culture on job-satisfaction.

$\mathrm{H}_{03}=$ There is no direct effect of work motivation on job-satisfaction.

$\mathrm{H}_{04}=$ There is no direct effect of organizational culture on job-performance.

$\mathrm{H}_{05}=$ There is no direct effect of work motivation on job-performance.

$\mathrm{H}_{\mathrm{ob}}=$ There is no direct effect of of job-satisfaction on job-performance.

$\mathrm{H}_{\mathrm{o} 7}=$ There is no indirect effect of organizational culture on job-satisfaction through work motivation.

$\mathrm{H}_{08}=$ There is no indirect effect of organizational culture on job-performance through work motivation.

$\mathrm{H}_{09}=$ There is no indirect effect of organizational culture on job-performance through job-satisdaction.

$\mathrm{H}_{\mathrm{o} 10}=$ There is no indirect effect of organizational culture on job-performance through work motivation and job-satisfaction.

$\mathrm{H}_{\mathrm{o} 11}=$ There is no indirect effect of work motivation on job-performance through job-satisfaction.

\section{Research Findings}

\subsection{Determination of Correlation Coefficients}

By using SPSS for Windows it was found coefficient correlations of the investigated variables as shown in Table 3.

Table 3. Coefficient correlations and one-sample kolmogorov-smirnov values

\begin{tabular}{cc}
\hline Coefficient Correlations Significant at the 0.01 level (2-tailed) & Kolmogorov-Smirnov-test. ${ }^{\text {a } A s y m p . S i g ~(2-t a i l e d) ~}>0.05$ \\
\hline $\mathrm{r}_{12}=0.333$ & $\mathrm{X}_{1}=0.125$ \\
$\mathrm{r}_{13}=0.312$ & $\mathrm{X}_{2}=0.106$ \\
$\mathrm{r}_{23}=0.338$ & $\mathrm{X}_{3}=0.109$ \\
$\mathrm{r}_{14}=0.408$ & $\mathrm{X}_{4}=0.071$ \\
$\mathrm{r}_{24}=0.391$ & \\
$\mathrm{r}_{34}=0.357$ & \\
\hline
\end{tabular}

a. Test distribution is Normal

The results showed that $\mathrm{X}_{1}, \mathrm{X}_{2}, \mathrm{X}_{3}$, and $\mathrm{X}_{4}$ coefficient correlations are significant at the 0.01 level (two tailed).

\subsection{Normality Test}

Normality test was carried out using One-Sample Kolmogorov-Smirnov Test and the results shown in Table 3. It was found that the samples were normally ditributed at the Asymp. $>0.05$. Sig. level (2-tailed).

\subsection{Hypothesis Testing}

Hypothesis 1:

$\mathrm{H}_{01}=$ There is no direct effect of organizational culture on work motivation.

Organiztional culture and work motivaion data were analyzed by SPSS for MS Windows and the results are displayed in Table 4 and 5.

Table 4. Path coefficient values

\begin{tabular}{ccc}
\hline Path Coefficients & $\mathrm{t}$-values & Sig. (2-tailed) \\
\hline$\rho_{21}=0.333$. & $\mathrm{t}=4.190$ & sig. $=0.000$ \\
$\rho_{31}=0.225$ & $\mathrm{t}=2.732$ & sig. $=0.000$ \\
$\rho_{32}=0.263$ & $\mathrm{t}=3.204$ & sig. $=0.000$ \\
$\rho_{41}=0.269$ & $\mathrm{t}=3.414$ & sig. $=0.001$ \\
$\rho_{42}=0.236$ & $\mathrm{t}=2.972$ & sig. $=0.003$ \\
$\rho_{43}=0.193$ & $\mathrm{t}=2.450$ & sig. $=0.016$ \\
\hline
\end{tabular}

Based on data calculated in Table 4, and table 5 that path coefficient of organizational culture to work motivation is 0.333 at a significant level of $<0.05$ and $\mathrm{F}=17.553$, where $\mathrm{F}_{\text {calc. }}>\mathrm{F}_{1 / 141}=3.908$, at a significant level of $<0.05$, 
so that $\mathrm{H}_{01}$ is rejected, and it can be mentioned that there is a direct effect of organizational culture on teacher work motivation of public high school investigated.

Hypothesis 2 and 3.

$\mathrm{H}_{02}=$ There is no direct effect of organizational culture on job-satisfaction

$\mathrm{H}_{03}=$ There is no direct effect of work motivation on job-satisfaction

Path coefficient of organizational culture to job-satisfaction is 0.225 , and work motivation to job-satisfaction is 0.263 respectively at a significant level of $<0.05$ and $F=13.224$, where $F_{\text {calc. }}>F_{2 / 140}=3.061$, at a significant level of $<0.05$, as a result $\mathrm{H}_{02}$ and $\mathrm{H}_{03}$ are rejected, and it is concluded that there is a direct effect of organizational culture and work motivation on the teacher job-satisfaction of public high school respectively...

Hypothesis 4, 5, and 6 .

$\mathrm{H}_{04}=$ There is no direct effect of organizational culture on job-performance

$\mathrm{H}_{05}=$ There is no direct effect of work motivation on job-performance

$\mathrm{H}_{\mathrm{ob}}=$ There is no direct effect of of job-satisfaction on job-performance

Path coefficient of organizational culture to job-performance is 0.269 , path coefficient of work motivation to job-performanc is 0.236 , and path coefficient of job-satisfaction to job-performanc is 0.193 respectively at a significant level of $<0.05$, and $F=17.261$, where $F_{\text {calc. }}>F_{3 / 139}=2.669$, at a significant level of $<0.05$. Therefore, $\mathrm{H}_{04}, \mathrm{H}_{05}$, and $\mathrm{H}_{06}$ are rejected, and it is concluded that there is a direct effect of organizational culture, work motivation, and job-satisfaction on job-performance respectively.

Hypothesis 7, 8, 9, 10 and 11 .

$\mathrm{H}_{07}=$ There is no indirect effect of organizational culture on job-satisfaction through work motivation

$\mathrm{H}_{08}=$ There is no indirect effect of organizational culture on job-performance through work motivation

$\mathrm{H}_{09}=$ There is no indirect effect of organizational culture on job-performance through job-satisdaction

$\mathrm{H}_{\mathrm{o} 10}=$ There is no indirect effect of organizational culture on job-performance through work motivation and job-satisfaction.

$\mathrm{H}_{\mathrm{ol1}}=$ There is no indirect effect of work motivation on job-performance through job-satisfaction.

Based on Figure 1, indirect effect of orgaizational culture, and work motivation toward job-satisfaction and job-performance can be determined.

(1). First, indirect effect of organizational culture on job-satisfaction through work motivation is $\rho_{32} \mathrm{r}_{12}=0.087$, therefore $\mathrm{H}_{07}$ is rejected and it is concluded that there is a direct effect of organizational culture on job-satisfaction through work motivation.

(2). Secondly, indirect effect of organizational culture on job-peformance through work motivation is $\rho_{42} \rho_{21}=$ 0.078 , it means that $\mathrm{H}_{08}$ is rejected, and it is concluded that there is an indirect effect of organizational culture on job-peformance through work motivation.

(3). Then, indirect effect of organizational culture on job-peformance through job-satisfaction is $\rho_{43} \rho_{31}=0.043$ (not significant), it means $\mathrm{H}_{09}$ is accepted.

(4). Forthermore, Indirect effect of organizational culture on job-peformance through work motivation and jobsatisfaction is $\rho_{32} \rho_{21} \rho_{43}=0.016$ (not significant), it means that $\mathrm{H}_{010}$ is accepted.

(5). Finally, Indirect effect of work motivation on job-performance through job-performance is $\rho_{43} \rho_{32}=0.193 \mathrm{x}$ $0.263=0.051$, (not significant), it means $\mathrm{H}_{011}$ is accepted.

Based on the data analysis, determinant coefficients were listed in the folowing Table 5.

Table 5. Determinant coefficients of R-square values

\begin{tabular}{llllll}
\hline & $\mathrm{R}$ & $\mathrm{R}$-square & df & $\mathrm{F}$ \\
\hline Model 1* & 0.333 & 0.111 & $1 / 141$ & 17.553 \\
Model 2** & 0.399 & 0.159 & $2 / 140$ & 0.000 & 13.244 \\
Model 3.*** & 0.521 & 0.271 & $3 / 139$ & 0.000 & 17.261 \\
\hline
\end{tabular}

*Predictor $\mathrm{X}_{1}$, independent variable $\mathrm{X}_{2 ;}$ **Predictors $\mathrm{X}_{1}$ and $\mathrm{X}_{2}$; independent variable $\mathrm{X}_{3}$

*** Predictors $\mathrm{X}_{1}, \mathrm{X}_{2}$ and $\mathrm{X}_{3}$; independent variable $\mathrm{X}_{4}$ 
As shown in Table 5, that determination coefficient $\mathrm{R}_{\text {square }}$ values for Model 1, 2 and 3 are 0.111., 0.159 and 0.272 respectively, so that

$\mathrm{e}_{2}=\sqrt{1-R^{2}}=\sqrt{1-0.333^{2}}=0.943$,

$\mathrm{e}_{3}=\sqrt{1-R^{2}}=\sqrt{1-0.399^{2}}=0.917$ and

$\mathrm{e}_{4}=\sqrt{1-R^{2}}=\sqrt{1-0.521^{2}}=0.854$.

\section{Goodness of Fit Model Test}

Goodness of fit model test is used to test whether the sugessted model fits data obtained or not. A general formulae used to determine Goodness of Fit Model is

$$
\mathbf{Q}=\frac{1-R^{2} m}{1-M} \text { (Pedhazur, 1982, p. 619) }
$$

where, $R^{2} m=1-\left(1-R_{1}{ }^{2}\right)\left(1-R_{2}^{2}\right)\left(1-R_{3}{ }^{2}\right)\left(1-R_{4}{ }^{2}\right)$,

Infact, all of the path coefficients found were significant, so that $M=R^{2} m$, and $Q=1$, therefore the suggested model is perfectly fit with the data collected, as a result the model can be illustrated in Figure 2 below:

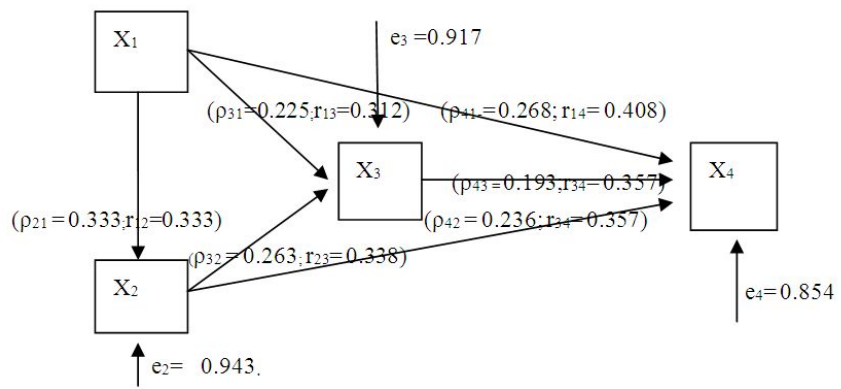

Figure 2. Teacher job-performance model suggested

\section{Discussion}

Based on the results above, it was found that effect of organizational culture to work motivation is $33.30 \%$, it means that organizational culture as "the glue" in school organization works well to motivate teachers. Previous results also support this finding and found that organizational culture affects teacher work motivation (Pamudjono, 2015, p. 20; Hutabarat, 2015a, p. 1; Hutabarat, 2015b, p. 1; Cucu-Ciuhan \& Guita-Alexandru, 2014, p. 4; Hutabarat, Situmorang, \& Pangaribuan, 2014, p. 272; Siburian, 2013, p. 15; Adhi, Hardienata, \& Sunaryo, 2013, p. 537; Pramudjono, 2013, p. 302).

In addition it was found that effect of organizational culture to job-performanc is $26.90 \%$, It shows how the power of culture in shaping schools and enchancing school performance (Peterson \& Deal, 1998, p. 28) It was also found that many schools have strong positive cultures, in which staffs have a shared sense of purpose, where they pour their hearts into teaching, and hard work in order to pursue school goals (Peterson, \& Deal, 1998, p. 29). It is shown also that effect organizational culture to job-satisfaction is $22.50 \%$. Indirect effect of organizational culture to job-satisfaction through work motivation is $8.70 \%$, and indirect effect of organizational culture to job-peformance through work motivation is $7.80 \%$. It is therefore, culture that shapes all aspect of schools include how the staff dresses, what staffs talk at schools, how teachers focuss on curriculum, and willingnes to change. (Valentine, 2006, p. 1; Hutabarat, 2015, p. 1b). The significant of efective and collaborative school culture encourage teachers to work collaboratively with each other, and with the staffs, to teach students so they are motivated (Valentine, 2006, p. 1). A school culture influencing the ways people think, feel and act, consequently, it is a key to school's success in promoting students and teachers (Peterson, 2002, p. 1). If culture does not support teaching and learning environment, the students will suffer from (Macneil, Prater, \& Bush, 2009, p. 73).

Effect of work motivation to job-satisfaction is $26.30 \%$. and effect of work motivation to job-performanc is $23.60 \%$, meanwhile effect of job-satisfaction to job-performanc is $19.30 \%$. Other results support this results which showed that there is a positive relationship between work motivation and teacher job-satisfaction (Hutabarat, 2015b, p. 1; Hutabarat, Situmorang, \& Pangaribuan, 2014, p. 269; Maharjan, 2012, p. 45). In fact, high motivation encreases productivity which is natural in all educational systems (Ololube, 2005; Ololube, 2004). It explains why school organizations have been interested in motivation which leads to job satisfaction of the teachers (Seniwoliba, 2013, p. 181). 
Total effect of organizational culture, work motivation and indirect effect of organizational culture to job-satisfaction is $64.9 \%$. It was also found that effect of job-satisfaction on job-performance is $19.30 \%$. Therefore, the overall total effect of organizational culture, work motivation and job-satisfaction and indirect effect of organizational culture to job-performance is $77.60 \%$. This percentage showed that organizational culture is considered as a main key to bind teachers and staffs to work together in pursuing school goals. As a result teachers were motivated to do their jobs and result in affecting job-satisfaction and finally affect teacher job-performance.

\section{Conclusions}

Based on the results shown above, it is concluded that, organizational culture affects work motivation, job-satisfaction and iob-performance respectively and significantly. In addition, work motivation also affects job-satisfaction and job-performance significantly. There is also indirect effect of organizational culture on job-satisfaction and on job-performance through work motivation respectively. However, there is no indirect effect of organizational culture on job-performance through job-satisfaction, and through work motivation and job-satisfaction respectively. There is no indirect effect of work motivation on job-performance through job-satisfaction. However, there is a significant direct effect of job-satisfaction to job-performance.

It was found that Job-performance model suggested fits with the data collected, therefore it is considered as a promising job-performance model for predicting teacher-performance and as feedback for teacher cariers and promotions.

\section{Acknowledgement}

I would like to thank Directorate General of Higher Education of Indonesia, for funding this research. In addition, I would like to thank Prof.. M. Sirait, Ph.D., and Prof. P. Pangaribuan, Ph.D. for their contributions and supports in finishing touch of this article.

\section{References}

Adejumobi, F. T., \& Ojikutu, R. K. (2013). School Climate and Teacher Job Performance in Lagos State Nigeria. Discourse Journal of Educational Research, 1(2), 26-36. Retrieved from http://www.resjournals.org/IJER

Adhi, S., Hardienata, S., \& Sunaryo, W. (2013). The Effect of Organizational Culture, Transformational Leadership and Work Motivation toward Teacher Performance. Indian Journal of Positive Psychology, 4(4), 537-539.

Amstrong, A. (2012). Build Higher Levels of Job Satisfaction. The leading Teacher, 7(6). 1-5. Retrieved from $\mathrm{http} / / /$ learningforward.org/docs/leading-teacher/may12_teacher.pdf?sfvrsn=2

Bell, B. (2012). A summary of motivation theories (pp. 1-26). Reprieved from http://www.yourcoach.be/blog/ wp-content/uploads/2012/03/A-summary-of-motivation-theories1.pdf

Colquitt, J. A., LePine, J. A., \& Wesson. M. J. (2009). Organizational Behavior, Improving performance and Commitment in the Workplace. McGraw Hill. International Edition., Singapore.

Cook, A. L. (2008). Job Satisfaction And Job Performance: Is The Relationship Spurious? (Master'sThesis). Retrieved from http://repository.tamu.edu/bitstream/handle/1969.1/etd-tamu-3052/cook-thesis.pdf?sequence $=1$

Cucu-Ciuhan, G., \& Guita-Alexandru, I. (2014). Organizational Culture Versus Work Motivation for Academic Staff in a Public University. Science Direct. Procedia Social and Behavioral Science, 127, 448-453. http://dx.doi.org/10.1016/j.sbspro.2014.03.288

Gultom, S. (2012). Pembinaan dan Pengambangan Guru, Buku 2. Pedoman Pelaksanaan Penilaian Kinerja Guru. Kementerian Pendidikan dan Kebudayaa, Badan pengambangan Sumber Daya Manusia, Pendidikan dan Kebudayaan dan Penjamianan Mutu Pendidikan, Pusat Pengambangan Profesi Pendidik (pp. 1-36).

Hanjun, K., Roberts, M. S., \& Chang-Hoan, C. (2006). Cross-Cultural Differences in Motivations and Perceived Interactivity: A Comparative Study of American and Korean Internet. Users. Journal of Current Issues and Research in Advertising, 28(2), 93-104. http://dx.doi.org/10.1080/10641734.2006.10505201

Hutabarat, W. (2015a). Do Organizational Structure and Organizational Culture Affect Teachers' Work Motivation to Some Extent. International Journal of Sciences: Basic and Applied Research (IJSBAR), 20(2), 350-362.

Hutabarat, W. (2015b). Impact of Organizational Culture, Organizational Structure and Job-Satisfaction on High School Teacher Job-Performance. Jurnal Cakrawala Pedidikan. 
Hutabarat, W., Situmorang, M., \& Pangaribuan, P. (2014). Effect of Organizational Culture, Organizational Structure, and Work Motivation on Job Satisfaction of Senior High School Teachers in Medan. International Journal of Sciences: Basic and Applied Research (IJSBAR), 16(1), 261-275

Inayatullah, A., \& Jehangir, P. (2002). Teacher's Job Performance: The Role of Motivation. Journal of Social Sciences, 5(2), 78-99. Retrieved from http://64.17.184.140:/wp-content/ uploads 2013/02/V5I2-6.pdf

Iwu, C. G., Gwija, S. A., Benedict, H. O., \& Tengeh, R. K. (2013). Teacher Job Satisfaction and Learner Performance in South Africa. Journal of Economics and Behavioral Studies, 5(12), 838-850. Retrieved from http://www.academia.edu/5742703/Teacher_job_satisfaction_and_learner_performance_in_South_ Africa

Judge, T. A., Bono, J. E., Thorensen, C. J., \& Patton, G. K. (2001). The Job-Satisfaction - Job-Performance Relationship: A Qualitative and Quantitative Review. Psychological Review, 127(3), 376-407. http://dx.doi.org/10.1037/0033-2909.127.3.376

Latt, K. A. (2008). Motivating people on the way towards organizational performance. Covalence, ethycal Quatation Syatem. Covalence Analyst Papers, Victoria University (Australia). Retrieved from http://www.ethicalquote.com/docs/Motivatingpeople.pdf

Luthams, G. P., \& Pinder, C. C. (2005). Work Motivation Theory and Research at the Dawn of the Twenty-First Century. Annu. Rev. Psychol., 56, 485-516. http://dx.doi.org/10.1146/annurev.psych.55.090902.142105

MacNeil, A. J., Prater, D. L, \& Bush, S. (2009). The Effect of Scholl Culture and Climate on Student Achievement. International Journal. Leadership in Education, 12(1), 73-84. http://dx.doi.org/10.1080/ 13603120701576241

Maharjan. S. (2012). Association between Work Motivation and Job-satisfaction at College Teachers, Association between Work Motivation and Job Satisfaction of College Teachers. Administrative and Management Review, 24(2), 45-55.

Mustafa, M., \& Othman, N. (2010). The Effect of Work Motivation on Teacher's Work Performance in Pekanbaru Senior High Schools, Riau Province, Indonesia. Sosiohumanika, 3(2), 259-272. Retrieved from http://64.17.184.140/wp-content/uploads/2013/02/V5I2-6.pdf

O’Donnel, O. O., \& Boyle, R. (2008). Understanding and Managing Organisational Culture. CPMR Discussion Paper 40. Institute of Public Administration, Printed by Colour Books Ltd, Dublin. Ireland. Retrieved from http://www.cpmr.gov.ie/Documents/Understanding\%20and\%20Managing\%20Organisational\%20Culture.pd $\mathrm{f}$

Ololube, N. P. (2004). Teachers job satisfaction and motivation for school effectiveness: An assessment. Helsinki: University of Helsinki, Finland. Retrieved from http://www.usca.edu/essays/vol182006/ololube.pdf

Ololube, N. P. (2005). Benchmarking the Motivational Competencies of Academically Qualified Teachers and Professionally Qualified Teachers in Nigerian Secondary Schools. The African Symposium, 5(3), 17-37. Retrieved from http://www.ololube.com/art6.pdf

Pedhazur, E. J. (1982). Multiple Regression in Behavioral Research, Explanation and Prediction (2nd ed.). Holt, Rinehartd and Winston, New York.

Peterson, K. D., \& Deal, T. E. (1998). Realizing a Positive School Climate, How Leaders Influence the Culture of Schools. Educational Leadership, 56(1), 28-30. Retrieved from https://arrycuban.files.wordpress.com/ 2012/08/el199809_peterson-1.pdf

Peterson. K. D. (2002). Enchancing School Culture, Reculturing Schools. Journal of Staff Development, 23(3), 1-5. Rertieved from http://smhp.psych.ucla.edu/qf/burnout_qt/reculturingschools.pdf

PISA. (2012). Results: What Students Know and Can Do Student Performance in Mathematics, Reading and Science, 1, 1-564. Retrieved from http://www.universityworldnews.com/article.php?story=20080904153 507452

Pramudjono. (2013). The Influence of Organizational Culture, Level of Moral Hierarchy and Motivation on the Commitment of High school Teachers in Samarinda. Second International Seminar on Quality and Affordable Education (ISQAE 2013), 302-306.

Pramudjono. (2015). The Influences of Organizational Culture, Moral Hierarchy Level, and Motivation towards the Teacher's Commitment. American Journal of Educational Research, 3(1), 20-24. http://dx.doi.org/10.12691/education-3-1-5 
Robbins, S., Judge, T., \& Sanghi, S. (2009). Organizational Behavior (13th ed.). New Delhi: Pearson Education.

Schall, M. S. (1993). A Communication-Rules Approach to Organizational Culture. Administrative Science Quarterly, 28, 557-581. http://dx.doi.org/10.2307/2393009

Schein, H. E. (2004). Organizational Culrtue and Leadership (3rd ed.). Jossey Bass. A Wiley imprint., USA.

Seniwoliba, A. J. (2013). Teacher Motivation and Job Satisfaction in Senior High Schools in the Tamale Metropolis of Ghana. Journal of Education and Review, 1(9), 181-196.

Siburian, T. A. (2013). The Effect of Interpersonal Communication, Organizational Culture, Job Satisfaction, and Achievement Motivation to Organizational Commitment of State High School Teacher in the District Humbang Hasundutan, North Sumatera, Indonesia. International Journal of Humanities and Social Science, $3(12), 1-15$.

Siruri, M. M., \& Muahe, S. M. A. (2014). A Critical Review of Literature on Job Designs in Socio-technical Systems. Global Journal and Management perspective, G.J.C.M.P., 3(6), 44-49.

Tella, A., Ayeni, C. O., \& Ppoola, S. O. (2007). Work Motivation, Job Satisfaction, and Organizational Commitment of Library Personnel in Academic and Research Libraries in Oyo State, Nigeria. Library Philosophy and Practice, (April), 1-17. Retrieved from http://digitalcommons.unl.edu/cgi/viewcontent.cgi? article $=1118 \&$ context=libphilprac

Tienken, C. (2008). Rankings of International Achievement Test Performance and Economic Strength: Correlation or Conjecture? International Journal of Education Poiicy and Leadership, 3(4), 1-15. Retrieved from http://www.ijepl.org

Valentine. J. (2006). A collaborative culture for School Improvement, definition and development, Research Summary. Middle Level Leadership Center. MLLC. Retrieved from http://education.missouri.edu/orgs/mllc/ Upload\%20Area-Docs/MLLC\%20Culture\%20Research\%20Summary.pdf

Weber, R. A., Camerer, C., \& Selein, R. (2006). The Effects of Organizational Structure and Codes on the Performance of Laboratory. 'Firms', Department of Social \& Decision Sciences, Carnegie Mellon University, Pitsburg, USA.

Wilkins, A. I., \& Ouchi, W. G. (1983). Efficient Cultures: Exploring the Relationship Between Culture and Organizational Performance. Administrative Science Quarterly, 28, 468-481. http://dx.doi.org/10.2307/ 2392253

\section{Copyrights}

Copyright for this article is retained by the author(s), with first publication rights granted to the journal.

This is an open-access article distributed under the terms and conditions of the Creative Commons Attribution license (http://creativecommons.org/licenses/by/3.0/). 